\title{
PENGARUH PENGGUNAAN MEDIA PEMBELAJARAN AUDIO VISUAL TERHADAP KEMAMPUAN MENYIMAK KELOMPOK B TK GUGUS II BULELENG
}

\author{
Ni Wayan Rian Astami ${ }^{1}$, Ni Ketut Suarni ${ }^{2,}$ Putu Aditya Antara ${ }^{3}$ \\ ${ }^{13}$ Jurusan Pendidikan Dasar \\ 2Jurusan IImu Pendidikan Psikologi, dan Bimbingan Konseling \\ Universitas Pendidikan Ganesha \\ Singaraja, Indonesia
}

\begin{abstract}
Email: niwayanrianastami26@gmail.com¹, niketut.suarni@Undiksha.ac.id², putuaditya.antara@undiksha.ac.id ${ }^{3}$
\end{abstract}

\begin{abstract}
Abstrak
Penelitian ini bertujuan untuk mengetahui perbedaan kemampuan menyimak antara kelompok anak yang diberikan media pembelajaran audio visual dan anak yang diberikan media gambar pada anak kelompok $\mathrm{B}$ TK Gugus II Kecamatan Buleleng tahun ajaran 2018/2019. Jenis penelitian ini adalah quasi experiment dengan rancangan Non-equivalen Post Test Only Control Group Design. Populasi dalam penelitian ini yaitu siswa TK kelompok B Gugus II Kecamatan Buleleng dengan melibatkan 426 responden. Teknik pengambilan sampel yang digunakan adalah random sampling. Sampel penelitian yaitu siswa TK Pradnya Paramita Singaraja yang berjumlah 20 orang sebagai kelas eksperimen dan siswa TK Widya Kumara Sthana Singaraja yang berjumlah 18 orang sebagai kelas kontrol. Data penelitian ini dikumpulkan dengan metode observasi berupa lembar observasi. Data yang dikumpulkan dianalisis menggunakan analisis deskriptif uji-t. Berdasarkan hasil analisis uji-t menggunakan SPPS 16.0 for windows diperoleh nilai sig (2tailed) $=0,000$ sedangkan pada taraf signifikansi $5 \%=0,05$, maka sig (2-tailed) $=0,000<0,05$ sehingga $\mathrm{H}_{0}$ ditolak dan $\mathrm{H}_{1}$ diterima. Hasil penelitian ini menunjukkan bahwa terdapat perbedaan yang signifikan kemampuan menyimak pada anak yang dibelajarakan dengan media pembelajaran audio visual dan yang dibelajarkan berupa media gambar pada anak kelompok B di TK Gugus II Kecamatan Buleleng Tahun Pelajaran 2018/2019
\end{abstract}

Kata-kata kunci: media audio visual, kemampuan menyimak, anak usia dini.

\begin{abstract}
This study was aimed to know the difference of listening skills between groups of children who were given audio-visual learning media and children who were given picture media for children in group B TK Gugus II Buleleng sub-district in academic year 2018/2019. The type of this research is Non-equivalen Post Test Only Control Group Design. The population in this study were kindergarten students group B, Gugus II, Buleleng sub-district which involving of 426 respondents. The sampling technique used is random sampling. The research sample was 20 stuudents as the experimental class from Pradnya Paramita Singaraja kindergarten and 18 students as the control class from Kumara Sthana Singaraja kindergarten. The data of this study were collected by observation method using an observation sheet. Data's collection was analyzed using t-test descriptive analysis. Based on the results of the t-test analysis using SPPS 16.0 for windows, the value of sig (2-tailed) $=0,000$ while at the significance level of $5 \%=0.05$, then sig (2-tailed) $=0,000$ $<0.05$ so $\mathrm{HO}$ is rejected and $\mathrm{H} 1$ is accepted. The results of this study indicate that there are significant differences in listening skills for children learned by using audio visual learning media and children learned by using picture media in group B children in TK Gugus II Sub District of Buleleng Academic Year 2018/2019.
\end{abstract}

Keywords: audio-visual media, listening skills, early childhood. 


\section{PENDAHULUAN}

Pendidikan dipandang sebagai proses yang sangat bermanfaat di dalam kehiduapan bukan hanya semata-mata sebagai persiapan untuk memasuki ke jenjang yang lebih tinggi. Taman Kanak-kanak (TK) merupakan salah satu lembaga pendidikan Anak Usia Dini yang bersifat formal. Anak Usia Dini merupakan periode (golden age) dimana pada masa itu anak berada dalam pertumbuhan yang sangat pesat, dan anak berada pada masa tumbuh kembang. Pada masa pertumbuhan dan perkembangan yang sangat pesat ini, sebaiknya anak diberikan pendidikan sedini mungkin. Usia lahir sampai enam tahun merupakan usia yang menentukan dalam pembentukan karakter dan kepribadian seorang anak. Anak usia dini berada pada tahap praoperasional dimana pada tahap ini anak masih egosentris sehingga terkesan pelit karena anak tidak bisa melihat dari sudut pandang orang lain. Anak tersebut juga memiliki kecenderungan untuk meniru orang disekelilingnya, anak belum mengerti cara berfikir yang sistematis atau rumit, dan dalam menyampaikan pembelajaran harus menggunakan alat peraga karena anak belajar dari benda-benda yang konkret. Oleh karena itu diperlukan lingkungan yang kondusif sehingga anak dapat bermain dan bereksplorasi secara langsung dan didukung oleh lingkungan sekitar. Mengingat dunia anak adalah dunia bermain sehingga segala stimulasi yang diberikan harus permainan yang menyenangkan agar mudah dipahami oleh anak. Pembelajaran yang dilakukan dengan bermain harus mengandung aspek perkembangan kognitif, bahasa, sosial emosional, moral, fisik motorik dan seni. Aspek perkembangan tersebut tidak berkembang dengan sendirinya, melainkan saling berintegrasi dan saling berhubungan satu sama lain. Menurut Sigel dan Coking (dalam Antara 2017:50) pemerolehan bahasa anak merupakan proses yang digunakan oleh anakanak untuk menyesuaikan serangkaian hipotesis dengan ucapan orang tua sampai dapat memilih kaidah tata bahasa yang baik dan sederhana yang bersangkutan.

Ada begitu banyak aspek perkembangan yang harus dikembangkan pada anak usia dini. Salah satu aspek yang harus dikembangkan adalah aspek perkembangan bahasa. Berdasarkan Peraturan Menteri Pendidikan dan Kebudayaan Republik Indonesia Nomor 137 Tahun 2014 pasal 10 tentang aspek perkembangan bahasa pada anak taman kanak-kanak, meliputi, (1) memahami bahasa reseftif, mencangkup kemampuan memahami cerita, perintah, aturan, menyenangi dan menghargai bacaan. (2) mengekspresikan bahasa, mencangkup kemampuan bertanya, menjawab pertanyaan, berkomunikasi secara lisan, menceritakan kembali apa yang sudah diketahui, belajar bahasa plagmatik, mengekspresikan perasaan, ide, dan keinginan dalam bentuk coretan (3) keaksaraan, mencangkup pemahaman terhadap hubungan bentuk dan bunyi huruf, meniru bentuk huruf, serta memahami kata dalam cerita. Menurut Santrock (2007:353) "Bahasa adalah suatu bentuk komunikasi baik itu lisan, tertulis atau isyarat yang berdasarkan pada suatu sistem dari simbol-simbol". Bahasa digunakan untuk mengekspresikan keunikan individu, untuk menjelasakan keinginan atau kebutuhan individu, mengubah dan mengontrol perilaku, membantu perkembangan kognitif dan mempererat interaksi kepada orang lain.

Bromley (dalam Karlina ddk, 2018:2) mengatakan "terdapat empat aspek kemampuan bahasa yaitu, menyimak, berbicara, membaca, dan menulis. Salah satu aspek kemampuan bahasa anak yang perlu distimulasi yaitu kemampuan menyimak. Menurut Sabarti (dalam Doludea dan Nuraeni, 2018:2) menyimak adalah suatu proses yang mencakup kegiatan mendengarkan bunyi bahasa, mengidentifikasi, menginterpretasi, menilai dan mereaksi atas makna yang terkandung di dalamnya. Brooks (dalam Dheini dkk, 2011:3.19) menyatakan, Kemampuan menyimak adalah sebagai salah satu kemampuan berbahasa awal yang harus dikembangkan, memerlukan kemampaun bahasa reseftif dan pengalaman, dimana anak sebagai penyimak secara aktif memproses dan memahami apa yang didengar. Berdasarkan beberapa pendapat di atas, maka dapat disimpulkan bahwa Kemampuan menyimak adalah salah satu kemampuan berbahasa yang di kembangkan melaui proses mendengarkan, memahami, mengevaluasi, dan menanggapi. Adapun indikator kemampuan menyimak dalam penelitian ini yaitu: mendengarkan orang berbicara, menerima pesan secara singkat, dapat menceritakan kembali, dapat melakukan instruksi secara lisan, menilai cerita, mengidentifikasi karakter dari tokoh cerita, memberikan reaksi terhadap informasi lisan, dan menjawab pertanyaan yang lebih kompleks.

Perkembangan kemampaun menyimak anak berkaitan erat satu dengan lainya, anak yang berkembang kemampuan menyimaknya akan berpengaruh terhadap kemapuan berbicaranya. Kedua keterampilan bahasa itu merupakan kegiatan komunikasi dua arah yang bersifat langsung 
dan dapat merupakan komunikasi yang bersifat tatap muka. Keterampilan menyimak dapat berfungsi untuk 1) menjadi dasar belajar bahasa, baik bahasa pertama maupun bahasa kedua. 2) menjadi dasar pengembangan kemampuan bahasa tulis (membaca dan menulis). 3) menunjang keterampilan bahasa lainnya. 4) memperlancar komunikasi lisan. 5) menambah informasi atau pengetahuan (Dhieni dkk, 2011:4.7). Ada tiga faktor yang memengaruhi kemampuan menyimak yaitu, 1) faktor menyimak yang berkaitan erat dengan tujuan, tingkat pemahaman, pengalaman dan strategi anak dalam memonitor pengalaman mereka terhadap informasi yang disampaikan. 2) faktor situasi berkatan dengan lingkungan sekitar anak dan stimulus visual yang diberikan. 3) faktor pembicara yaitu komunikasi yang dilaksanakan oleh pemberi dan pembawa informasi harus baik dan jelas (Dheini (2011:3.20). Dari faktor tersebut dibuktikan bahwa motivasi yang kuat diperlukan untuk anak pada saat menerima informasi, selain itu lingkungan sekitar dan cara berkomunikasi juga menjadi faktor yang memengaruhi baik buruknya kemampuan menyimak anak.

Jalongo (dalam Hartati dan Novrika, 2018:30) mengatakan karakteristik anak usia dini usia 56 tahun pada aspek kemampuan menyimak yaitu: mampu memahami cerita, mengidentifikasi karakter dari tokoh cerita, memahami bahasa dan kalimat dalam cerita, serta dapat menceritakan kembali cerita dengan detail. Adapun menurut Wilson \& Korn (dalam Kartikadewi dkk, 2018:167) kemampuan menyimak anak dapat diukur ketika anak 1) memusatkan perhatian dalam jangka waktu 10-15. 2) anak dapat melakukan instruksi lisan sederhana dari guru. 3) mendengarkan orang lain berbicara dan menanggapi suatu pesan atau informasi tertentu.

Tahap-tahap menyimak pada anak yaitu: 1) Anak mengenal bermacam-macam bunyi melalui pendengaran bunyi. Pada tahap ini guru mengajak anak mengamati dan mendengarkan bunyibunyi yang ada di sekitar sekolah. 2). Anak mengenal kata-kata yang hampir sama bunyinya melalui pengamatan. Pada tahap ini anak mengenal kata-kata yang hampir sama bunyinya dapat dicapai dengan jalan membimbing anak untuk dapat secara auditif (melalui pendengaran) membedakan kata-kata yang hampir sama bunyinya. 3). Anak memahami perintah, menerapkan dan mengkordinasikan perintah tersebut. Pada tahap ini dapat dicapai dengan membantu anak melalukan pengamatan dan melakukan perbuatan. 4). Anak berminat mendengarkan isi cerita dan dapat menghayati serta menghargainya. Pada tahap ini dapat dicapai dengan cara membimbing anak untuk mau mendengarkan cerita dari guru, menceritakan isi cerita kembali, dan bercakapcakap mengenai isi cerita. 5). Anak mengenal kalimat-kalimat sederhana dan membedakan kalimat benar dan salah. Pada tahap ini dapat dicapai dengan cara menjelaskan kepada anakanak makna dari kalimat-kalimat yang sering dijumpai sehari-hari dan memberikan alasan mengapa suatu kalimat tersebut benar dan kenapa yang lain salah (dalam Listyaninggrum, 27:2017)

Pembelajaran yang dilakukan untuk menstimulasi kemampuan menyimak anak hendaknya dilakukan melalui kegiatan yang menyenangkan dan dapat menarik minat anak untuk belajar. Sebagai seorang guru dalam menyampaikan materi pembelajaran haruslah mampu menggunakan media pembelajaran yang bervariasi dan inovatif agar anak lebih antusias mengikuti pembelajaran. Ketika guru ingin meningkatkan kemampuan menyimak anak usia dini juga harus melihat karakteristik anak. Anak usia dini berada pada tahap pra-operasional dimana pada tahap ini anak masih egosentris sehinga terkesan pelit karena anak tidak bisa melihat dari sudut pandang orang lain. Anak tersebut juga memiliki kecendrungan untuk meniru orang disekelilingnya, anak belum mengerti cara berfikir yang sistematis atau rumit, dan dalam menyampaikan pembelajaran harus menggunakan alat peraga karena anak belajar dari benda-benda yang konkret. (Filtri dan Sembiring 2018:173). Berdasarkan hal tersebut maka di perlukan media atau alat peraga yang sesuai dengan tahap perkembangan kemampuan menyimak anak.

Berdasarkan hasil observasi pada anak kelompok B di Taman Kanak-kanak Gugus II Kecamatan Buleleng tahun ajaran 2018/2019, diperoleh hasil bahwa guru sudah memberikan pembelajaran yang dapat menstimulasi kemampuan menyimak anak, namun ada beberapa anak yang kemampuan menyimaknya perlu ditingkatkan dengan media pembelajaran yang sesuai dengan karakterstik anak usia 5-6 tahun. Hal ini ditunjukkan dengan perilaku anak seperti, tidak mendengarkan guru berbicara di depan kelas, anak belum memahami apa yang disampaikan guru, saat dibacakan cerita anak masih ramai dengan teman, anak banyak sibuk sendiri dengan apa yang ada di mejanya dan diam tanpa memperhatikan. Ketika dilakukan percakapan seputar 
pembelajaran yang disampaikan, hanya beberapa anak yang memahami dan merespon pertanyaan yang diberikan oleh guru.

Melihat permasalahan ini, maka solusi yang dapat diberikan yaitu menggunakan media audio visual. Media ini lebih mudah digunakan dalam penyampaian materi pembelajaran sehingga anak lebih tertarik dalam mengikuti pembelajaran serta tidak membuat anak bosan karena terdapat kombinasi video, slide dan suara. Menurut Wina Sanjaya, (dalam Yuliana, 2018:18) media audio visual adalah media yang mempunyai unsur suara yang dapat didengar dan unsur gambar yang dapat dilihat. Misalnya seperti, rekaman video, slide, suara, dan sebagainya. Dimana dalam pembelajaran atau bercerita guru akan menggunakan media ini dan diiringi oleh suara atau musik yang mendukung pesan-pesan atau informasi yang ingin disampaikan dalam pembelajaran. Kelebihan penggunaan media audio visual ini sangat banyak seperti, pembelajaran yang dilakukan menjadi menyenangkan, guru-guru lebih mudah dalam menyampaikan pembelajaran, pembelajaran menjadi lebih menarik, anak merasa senang dan antusias untuk belajar. Apabila anak-anak menyukai pembelajaran menggunakan media audio visual ini maka anak-anak akan melakukan dengan penuh perhatian, sehingga tujuan pembelajaran dapat tercapai dengan optimal

Ibrahim, dkk. (dalam Tegeh, 2009:8) mengatakan, media pembelajaran adalah segala sesuatu yang dapat digunakan untuk menyalurkan pesan (bahan pembelajaran) sehingga dapat merangsang perhatian, minat, pikiran, dan perasaan pebelajar (anak) dalam kegiatan belajar untuk mencapai tujuan pembelajaran tertentu. Contoh: gambar, bagan, model, film, video, komputer, dan sebagainya. Menurut Wina Sanjaya, (dalam Yuliana, 2018:18) media audio visual adalah media yang mempunyai unsur suara yang dapat didengar dan unsur gambar yang dapat dilihat. Media audio visual adalah media yang mempunyai unsur suara dan unsur gambar, sehingga untuk menikmatinya diperlukan indera pendengaran dan penglihatan (Tegeh 2009:25). Media audio visual mempunyai banyak manfaat dalam pembelajaran, secara umum manfaat media pembelajaran audio visual yaitu dapat memudahkan anak untuk memahami informasi yang disampaikan.

Menurut Dale (dalam Yuliana, 2018:20), Media audio visual dapat memberikan manfaat asalkan guru berperan aktif dalam proses pembelajaran, manfaatnya adalah berikut ini: 1) Meningkatkan rasa saling pengertian dan simpati dalam kelas. 2) Membuahkan perubahan signifikan tingkah laku anak. 3) Membawa kesegaran dan variasi bagi pengalaman belajar anak. 4) Membuat hasil belajar lebih bermakna bagi berbagai kemampuan anak. 5) Memberikan umpan balik yang diperlukan yang dapat membantu anak menemukan seberapa banyak telah mereka pelajari. 6) Memperluas wawasan dan pengalaman anak. Menurut Dinda (2017:54) ada beberapa langkah penggunaan media audio visual yaitu. 1) membuat rencana pelaksanaan pembelajaran 2) mempelajari buku petunjuk penggunaan media 3) menyiapkan dan mengatur peralatan media yang akan digunakan 4) memastikan media dan semua peralatan telah lengkap dan siap digunakan 5) menjelaskan tujuan yang akan dicapai 6) menjelaskan materi pembelajaran kepada anak selama proses pembelajaran berlangsung.

Langkah-langkah perlakuan kelompok eksperimen menggunakan media pembelajaran audio visual untuk meningkatkan kemampuan menyimak anak. Pertemuan 1) yaitu guru melatih anak untuk memperhatikan dan mendengarkan guru menyampaikan materi di depan kelas. Apabila ada anak yang masih lain-lain dan tidak memperhatikan materi yang guru berikan, anak akan diberikan bimbingan. Pertemuan 2) guru melatih anak memperhatikan dan mendengarkan guru menyampaikan materi di depan kelas. Anak secara mandiri dapat memperhatikan dan mendengarkan guru menyampaikan materi di depan kelas. Pertemuan 3 dan 4 memperhatikan video yang di tampilkan di layar. Guru melatih anak untuk memperhatikan gambar-gambar dalam video yang ditampilkan, memperhatikan apa saja yang ada dalam video serta menyebutkannya. Pertemuan 5) anak memperhatikan video yang di tampilkan di layar. Anak secara mandiri dapat menyebutkan apa saja yang ada dalam video yang telah ditayangkan. Pertemuan 6 dan 7 menceritakan kembali secara sederhana isi dari video yang telah ditayangkan. Guru melatih anak untuk menceritakan kembali secara singkat isi dari video dengan menggunakan bahasa sederhana. Pertemuan 8) menceritakan kembali secara sederhana isi dari video yang telah ditayangkan. Anak secara mandiri dapat menceritakan kembali secara singkat isi dari video yang telah ditayangkan. Pertemuan 9 dan 10 menjawab pertanyaan dari guru dan bertanya kepada guru. Guru melatih anak untuk menjawab pertanyaan yang diajukan terkait dengan isi video serta 
guru juga melatih anak untuk bertanya kepada guru dengan bahasa sederhana. Pertemuan 11 menjawab pertanyaan dari guru dan bertanya kepada guru. Anak secara mandiri dapat menjawab pertanyan yang diberikan guru serta anak juga secara mandiri dapat bertanya kepada guru terkait dengan isi video yang ditayangkan. Pertemuan 12 Tahap evaluasi untuk memperoleh kemampuan menyimak pada anak dengan menggunakan media pembelajaran audio visual.

Berdasarkan uraian diatas, pada kesempatan ini perlu dirancang sebauh penenlitian yang berjudul "Pengaruh media pembelajaran audio visual terhadap kemampuan menyimak anak kelompok B Taman Kanak-kanak Gugus II Kecamatan Buleleng tahun ajaran 2018/2019". Adapun tujuan yang ingin dicapai dalam penelitian ini adalah untuk mengetahui perbedaan yang signifikan kemampuan menyimak antara kelompok anak yang diberikan media pembelajaran audio visual dengan anak yang diberikan media gambar pada anak kelompok B Taman Kanak-kanak Gugus II Kecamatan Buleleng tahun ajaran 2018/2019. Diharapkan dengan adanya penelitian ini dapat meningkatkan kemampuan menyimak anak.

\section{METODE}

Penelitian ini merupakan jenis penelitian eksperimen semu (quasi eksperiment) dengan rancangan yang digunakan dalam penelitian ini adalah Non-equivalen Post Test Only Control Group Design. Adapun populasi dalam penelitian ini adalah seluruh anak Taman Kanak-kanak kelompok B Gugus II Kecamatan Buleleng semester genap pada tahun ajaran 2018/2019 yang berjumalh 426. Gugus II terdiri dari 8 sekolah, sehingga dari 8 sekolah tersebut akan diambil 2 sekolah, satu sekolah sebagai kelompok eksperimen dan 1 sekolah sebagai kelompok kontrol. Berdasarkan kesetaraan sampel hasil pengundian pertama, selanjutnya dilakukan pengundian tahap kedua untuk menentukan kelas eskperimen dan kelas kontrol. Kelompok eksperimen diberikan perlakuan berupa media pembelajaran audio visual dan kelas kontrol yang diberikan perlakukan berupa media gambar.

Pengambilan sampel dalam penelitian ini dilakukan dengan teknik cluster sampling. Teknik cluster sampling dugunakan untuk menentukan siswa-siswa yang masuk ke dalam kelas eksperimen dan kelas kontrol. Data yang dikumpulkan dalam penelitian ini adalah data kemampuan menyimak anak. Untuk mengumpulkan data hasil belajar tersebut, dalam penelitian ini digunakan metode observasi. Intrumen pengumpulan data yang digunakan dalam penelitian ini adalah metode observasi. Menurut Nawawi dan Martini (dalam Agung, 2014:94) Observasi adalah pengamatan dan pencatatan secara sistematis terhadap unsur-unsur yang tampak dalam suatu gejala atau gejala-gejala dalam objek penelitian. Observasi dibagi menjadi dua, yaitu observasi terstruktur dan observasi tidak terstruktur. "Observasi terstruktur yaitu segala kegiatan observasi telah ditetapkan berdasarkan kerangka kerja yang menurut faktor-faktor yang telah diatur kategorinya". "Observasi tidak terstruktur adalah segala kegiatan observasi hanya mengacu pada tujuan penelitian" (Agung, 2014:96). Observasi dilakukan terhadap peneliti dan siswa dalam media pembelajaran audio visual terhadap kemampuan menyimak anak kelompok B. Instrumen yang digunakan dalam penelitian ini hanya menggunakan satu instrumen yaitu lembar observasi.

Sugiyono (2017:224) menyatakan bahwa instrumen penelitian adalah alat bantu pengumpulan dan pengelolaan data tentang variabel-variabel yang diteliti. Kisi-kisi instrumen dibuat sesuai dengan karakteristik setiap data. Penyusunan kisi-kisi instrumen yang disusun untuk mendapatkan kelengkapan data validitas instrumen. Untuk mendapatkan data yang diinginkan, maka disusunlah kisi-kisi instrumen kemampuan menyimak anak kemudian akan dituangkan dalam rubrik untuk memudahkan penilai. Agar memperoleh data dalam penelitian ini digunakan satu buah instumen yaitu instrumen kemampuan menyimak. Kemampuan menyimak adalah salah satu kemampuan berbahasa yang di kembangkan melaui proses mendengarkan, memahami, mengevaluasi, dan menanggapi. Dalam penelitian ini, analisis statistik deskriptif dilakukan dengan menyajikan data berupa angka rata-rata (Mean), media, modus, varians, dan standar deviasi. Teknik yang digunakan untuk menganalisis data guna menguji hipotesis penelitian adalah uji-t (volled varians) sebelum dilakukan uji hipotesis, terlebih dahulu dilakukan uji prasyarat yaitu uji normalitas sebaran data dan uji homogenitas varians. 


\section{HASIL DAN PEMBAHASAN}

Responden yang digunakan dalam penelitian ini sebanyak 38 anak, 20 orang anak sebagai kelompok eksperimen dan 18 orang anak sebagai kelompok kontrol. Pertemuan dalam penelitian ini sebanyak 12 kali pertemuan dimasing-masing kelompok. Kelompok eksperimen diterapkan pada kelompok $\mathrm{B}^{1}$ TK Pradnya Paramita Singaraja dan kelompok kontrol diterapkan pada kelompok B2 TK Widya Kumara Sthana Singaraja. Kelompok eksperimen diterapkan media pembelajaran audio visual, sedangkan pada kelompok kontrol diterapkan media pembelajaran berupa media gambar. Objek penelitian ini adalah kemampuan menyimak pada anak kelompok B. Data kemampuan menyimak kelompok anak yang dibelajarkan dengan menggunakan media pembelajaran audio visual menunjukkan bahwa skor tertinggi adalah 60 dan skor terendah adalah 46. Sebaran data skor kemampuan menyimak kelompok eksperimen dapat dilihat pada tebel 1. Data kemampuan menyimak kelompok eksperimen disajikan ke dalam bentuk grafik poligon seperti pada gambar 1.

Tabel1.

Deskripsi Data kemampuan menyimak anak

\begin{tabular}{ll}
\hline Hasil Analisis & $\begin{array}{l}\text { Kelompok } \\
\text { Eksperimen }\end{array}$ \\
\hline Mean & 51,35 \\
Median & 51,5 \\
Modus & 52,16 \\
Varians & 3,15 \\
Standar Deviasi & 9,92 \\
Skor max. & 60 \\
Skor min & 46 \\
Rentangan & 16 \\
\hline
\end{tabular}

Berdasarkan tabel 1 nilai rata-rata kemampuan menyimak kelompok eksperimen yang dibelajarkan menggunakan media pembelajaran media audio visual sebesar $=51,35$ dengan varians $=3,15$ dan standar deviasi 9,92. Sedangkan nilai rata-rata kemampuan menyimak kelompok kontrol yang dibelajarkan menggunakan media gambar sebesar $=39,94$ dengan varian $=20,25$ dan standar deviasi $=4,5$.

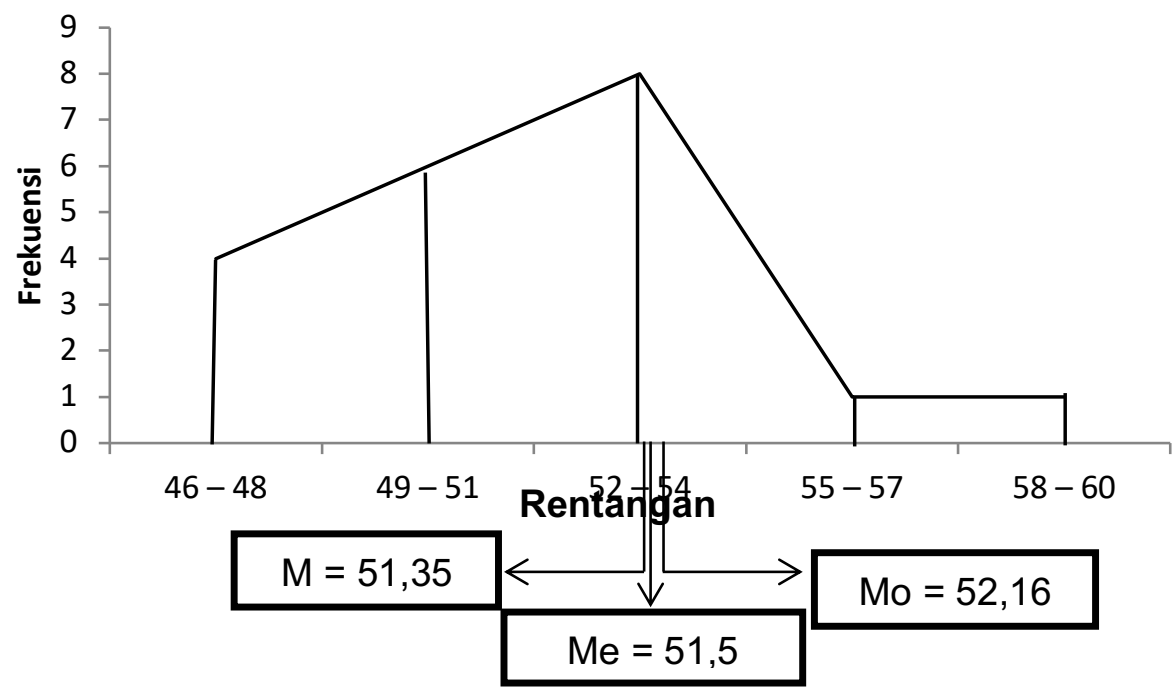

Gambar 1. Grafik poligon data kemampuan menyimak kelompok eksperimen 
Berdasarkan grafik poligon di atas, terlihat bahwa sebaran data kelompok anak yang dibelajarkan menggunakan media audio visual menunjukkan kurva juling negatif karena $\mathrm{Mo}>\mathrm{Me}>$ $M(52,16>51,5>51,35)$. Hal ini menunjukkan bahwa sebagian besar skor sendrung tinggi. Untuk mengetahui kualitas dari variabel kemampuan menyimak anak, skor rata-rata kemampuan menyimak anak kelompok eksperimen dikonversikan dengan menggunakan kreteria rata-rata ideal $\left(\mathrm{M}_{\mathrm{i}}\right)$ dan standar ideal $\left(\mathrm{SD}_{\mathrm{i}}\right)$. Hasil perhitungan $\mathrm{M}_{\mathrm{i}}$ dan $\mathrm{SD}_{\mathrm{i}}$ maka diperoleh hasil konversi seperti pada tabel 2.

Tabel 2

Kriteria rata-rata ideal dan standar deviasi ideal

\begin{tabular}{ll}
\hline Rentang Skor & Kategori \\
\hline $49,00-<60,00$ & Sangat tinggi \\
$41,00-<49,00$ & Tinggi \\
$34,00-<41,00$ & Sedang \\
$26,00-<34,00$ & Rendah \\
$15,00-<26,00$ & Sangat rendah \\
\hline
\end{tabular}

Hasil analisis data diperoleh bahwa mean kemampuan menyimak kelompok anak yang dibelajarkan dengan menggunakan media pembelajaran audio visual adalah 51,35 . Jika dikonversi ke dalam PAP skala lima berada pada katagori sangat tinggi.

Data kemampuan menyimak kelompok anak yang dibelajarkan dengan menggunakan media gambar menunjukkan bahwa skor tertinggi adalah 50 dan skor terendah adalah 30 . Sebaran data skor kemampuan menyimak dapat dilihat pada tebel 3. Data kemampuan menyimak kelompok kontrol disajikan ke dalam bentuk grafik poligon seperti pada gambar 2 .

Tabel 3

Tabel deskripsi data kemampuan menyimak anak

\begin{tabular}{ll}
\hline Hasil Analisis & Kelompok \\
& Kontrol
\end{tabular}

\begin{tabular}{ll}
\hline Mean & 39,94 \\
Median & 39,00 \\
Modus & 36,61 \\
Varians & 20,25 \\
Standar Deviasi & 4,5 \\
Skor Max. & 50 \\
Skor Min. & 30 \\
Rentangan & 21
\end{tabular}

Nilai rata-rata kemampuan menyimak kelompok kontrol yang dibelajarkan menggunakan media gambar sebesar $=39,94$ dengan varian $=20,25$ dan standar deviasi $=4,5$. 




Gambar 2. Grafik poligon data kemampuan menyimak kelompok kontrol

Berdasarkan grafik poligon di atas, terlihat bahwa sebaran data kelompok anak yang dibelajarkan menggunakan media gambar menunjukkan kurva juling positif karena $\mathrm{Mo}<\mathrm{Me}<\mathrm{M}$ $(36,61<39<39,94)$. Hal ini menunjukkan bahwa sebagian besar skor cenderung rendah. Untuk mengetahui kualitas dari variabel kemampuan menyimak anak, skor rata-rata kemampuan menyimak anak kelompok kontrol dikonversikan dengan menggunakan kriteria rata-rata ideal (Mi) dan standar ideal (SDi). Hasil perhitungan $\mathrm{M}_{\mathrm{i}}$ dan $\mathrm{SD}_{\mathrm{i}}$ maka diperoleh hasil konversi seperti pada tabel 4.

Tabel 4

Kriteria Rata-rata ideal dan standar deviasi ideal

\begin{tabular}{ll}
\hline Rentang Skor & Kategori \\
\hline $49,00-<60,00$ & Sangat tinggi \\
$41,00-<49,00$ & Tinggi \\
$34,00-<41,00$ & Sedang \\
$26,00-<34,00$ & Rendah \\
$15,00-<26,00$ & Sangat rendah \\
\hline
\end{tabular}

Hasil analisis data diperoleh bahwa mean kemampuan menyimak kelompok anak yang dibelajarkan dengan menggunakan media gambar adalah 39,94 Jika dikonversi ke dalam PAP skala lima berada pada katagori tinggi.

Sebelum melakukan uji hipotesis, terlebih dahulu melakukan pengujian prasyarat terhadap sebaran data yang meliputi uji normalitas pada data kelompok eksperimen dan kelompok kontrol serta dilakukan uji homogenitas antara kelompok terhadap sebaran data kemampuan menyimak. Berikut ini diuraikan mengenai hasil pengujian normalitas dan homogenitas terhadap data skor kemampuan menyimak. Berdasarkan analisis data yang dilakukan, rangkuman hasil uji normalitas sebaran data kemampuan menyimak kelompok eksperimen dan kontrol yang dapat dilihat pada tabel 5 .

Tabel 5

Rangkuman hasil uji normalitas sebaran data

Kelompok Data Hasil Belajar $\quad X^{2} \quad$ Nilai Kritis dengan Taraf Signifikansi $5 \% \quad$ Keterangan

\begin{tabular}{llll}
\hline Eksperimen & 5,22 & 11,07 & Normal \\
Kontrol & 3,97 & 11,07 & Normal \\
\hline
\end{tabular}

Berdasarkan perhitungan di atas hasil uji normalitas sebaran data kemampuan menyimak padataraf signifikansi $5 \%$ dan derajat kebebasan $\mathrm{dk}=$ jumlah baris $-1=(6-1=5)$, didapatkan harga Chi-square tabel 11,07 diperoleh kelompok anak yang dibelajarkan dengan media 
pembelajaran audio visual $X^{2}{ }_{\text {hit }}=5,22$, ini berarti bahwa $X^{2}{ }_{\text {hit }}(5,22)<X^{2}{ }_{\text {tab }}(11,07)$ maka data kemampuan meyimak kelompok anak yang dibelajarkan dengan media pembelajaran audio visual berdistribusi normal. Sedangkan hasil yang diperoleh kelompok anak yang dibelajarkan dengan media gambar $X^{2}{ }_{\text {hit }}=3,97$, ini berarti bahwa $X^{2}{ }_{\text {hit }}(3,97)<X^{2}{ }_{\text {tab }}(11,07)$ maka data kemampuan menyimak anak yang dibelajarkan menggunakan media gambar juga berdistribusi normal. Sedangkan hasil perhitungan uji homogenitas data kemampuan menyimak disajikan pada tabel 6.

Tabel 6

Rangkuman hasil uji homogenitas varians

\begin{tabular}{llllll}
\hline Sumber Data & Mean & Varians & $F_{\text {hitung }}$ & $F_{\text {tabel }}$ dengan taraf signifikansi 5\% & Status \\
\hline Kelompok & 51,35 & 9,92 & 2,04 & 4,11 & Homogen \\
$\begin{array}{l}\text { Eksperimen } \\
\text { Kelompok Kontrol }\end{array}$ & 39,94 & 20,25 & & & \\
\hline
\end{tabular}

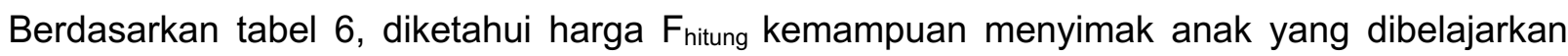
dengan media audio visual dan kelompok anak yang dibelajarkan dengan menggunakan media gambar adalah 2,04 dan $\mathrm{F}_{\text {tabel }}$ dengan df $1_{\text {pembilang }}=\mathrm{k}-1=2-1=1$, df $2_{\text {penyebut }}=\mathrm{n}-\mathrm{k}=38-2=$ 36 , dan taraf signifikansi $5 \%$ adalah 4,11 . Hal ini berarti $F_{\text {hitung }}<F_{\text {tabel }}$ sehingga varians data kemampuan menyimak dikategorikan homogen

Pengujian hopotesis $\mathrm{H}_{0}$ dan $\mathrm{H}_{1}$ dilakukan dengan menggunakan uji-t sampel independent (tidak berkorelasi). Karena $n_{1} \neq n_{2}$ dan hasil perhitungan varians menyatakan homogen, maka dalam pengujian digunakan rumus polled varians, dengan $\mathrm{db}=n_{1}+n_{2}-2$. Kriteria $\mathrm{H}_{0}$ ditolak jika $t_{\text {hit }}>t_{\text {tab }}$ dan $\mathrm{H}_{0}$ diterima jika $t_{\text {hit }}<t_{\text {tab. }}$. Rangkuman hasil perhitungan uji-t antar kelompok eksperimen dan kelompok kontrol disajikan pada tabel 7.

Tabel 7

Rangkuman hasil perhitungan uji-t Independent Samples Test

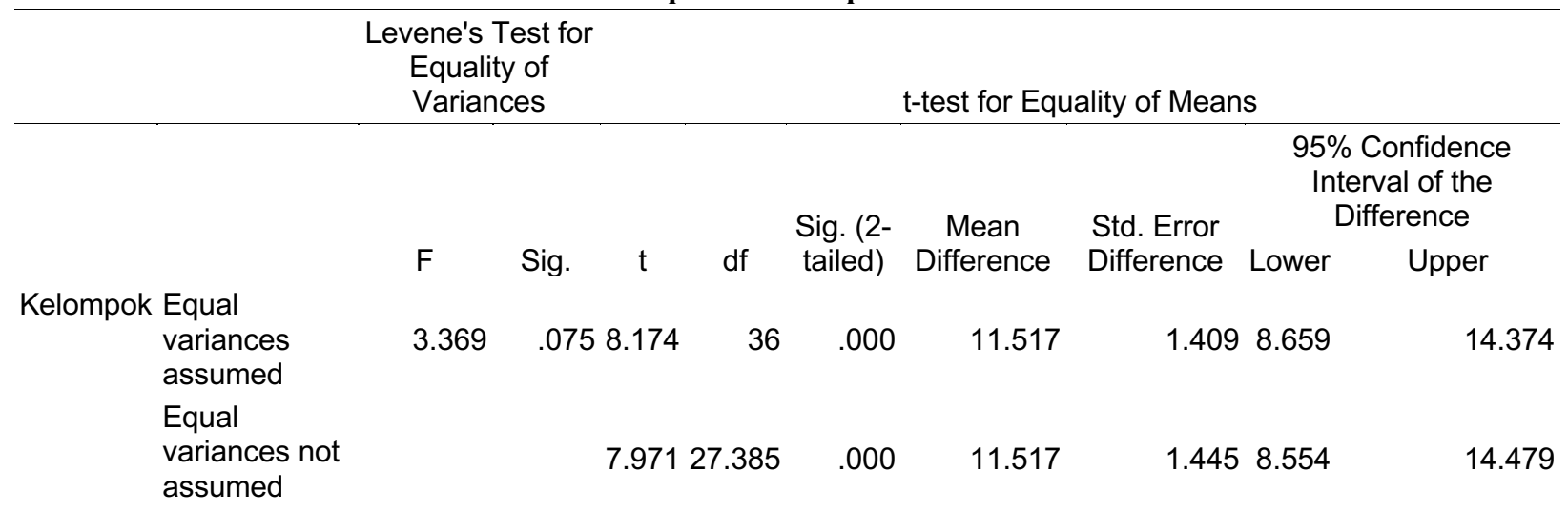

Berdasarkan Tabel 7 diperoleh nilai sig (2-tailed) sebesar $=0,000$ sedangkan pada taraf signifikan $5 \%=0,05$ maka sig (2-tailed) $=0,000<0,05$ sehingga $\mathrm{H}_{0}$ ditolak menyatakan hasil posttest kelompok eksperimen dan kelompok adalah signifikan (ada perbedaan). Jadi dapat disimpulkan bahwa terdapat perbedaan yang signifikan antara media pembelajaran audio visual dengan media gambar terhadap kemampuan menyimak anak kelompok B Taman Kanak-kanak Gugus II Kecamatan Buleleng tahun ajaran 2018/2019.

Perbedaan kemampuan menyimak kelompok eksperimen dengan kelompok kontrol terjadi karena kegiatan pembelajaran menggunakan media pembelajaran audio visual sehingga memberikan pengalaman anak untuk melihat objek atau gambar secara jelas serta suara yang mendukung objek tersebut. Anak akan menjadi lebih fokus untuk melihat objek tersebut dan mendengarkan apa yang telah disampaikan guru. Dengan menggunakan media pembelajaran ini anak dapat mendengarkan cerita dan melihat langsung melalui slide yang ditayangkan, anak juga dapat mengetahui perilaku apa saja yang boleh dilakukan dan tidak boleh dilakukan, serta anak 
dapat melihat langsung tokoh-tokoh yang ada dalam cerita. Hal ini sependapat dengan Wina Sanjaya, (dalam Yuliana, 2018:18) menyatakan bahwa, media audio visual adalah media yang mempunyai unsur suara yang dapat didengar dan unsur gambar yang dapat dilihat seperti: rekaman video, slide, suara. Selain itu, Media audio visual mempunyai peranan membantu guru dan anak didik dalam proses pembelajaran. Pembelajaran menggunakan media pembelajaran audio visual ini memberikan pengalaman anak untuk melihat objek atau gambar secara jelas serta suara yang mendukung objek tersebut. Anak-anak terlihat sangat antusias dan bersemangat dalam mengikuti kegiatan pembelajaran. Hal ini terlihat dari sikap anak ketika guru menyampaikan tujuan pembelajaran dan langkah-langkah- dalam melaksanakan pembelajaran menggunakan media audio visual.

Hasil temuan selama proses pembelajaran dengan menerapkan media pembelajaran audio visual yaitu, dapat meningkatkan rasa ingin tahu anak dan antusias untuk mengikuti pembelajaran yang diberikan guru. Anak begitu senang saat diberi tahu mengenai alat atau media yang akan digunakan dalam kegiatan belajar maupun bercerita. Sehingga diakhir pembelajaran anak-anak mampu mengetahui apa saja yang telah dilakukan saat proses pembelajaran, mampu mengetahui jalan cerita yang didengar, mengetahui pesan-pesan yang terkandung dalam cerita, mengetahui tokoh dalam cerita dan mampu menceritakan kembali cerita secara sederhana. Hal ini sependapat dengan Wina Sanjaya, (dalam Yuliana, 2018:18) menyatakan media audio-visual memberikan banyak stimulus kepada peserta didik, karena sifat audio visual/suara-gambar, sehingga memperkaya lingkungan belajar, memelihara eksplorasi, eksperimen dan penemuan, dan untuk mengembangkan pembicaraan dan mengungkapkan pikiranya. Suasana belajar juga terlihat aktif karena terjalin interaksi antara anak dengan anak maupun guru dengan anak. Kegiatan ini membuat anak lebih aktif dan terlibat langsung dalam proses pembelajaran, suasana yang terjadi dalam kelas pada saat proses pembelajaran menjadi lebih menyenangkan dan lebih kondusif. Selain itu, anak sudah mampu mengetahui perilaku apa saja yang boleh dilakukan dan tidak boleh dilakukan dari pembelajaran yang diterima, serta anak dapat melihat langsung tokohtokoh yang ada dalam cerita menggunakan media audio visual ini.

Berbeda halnya dengan media pembelajaran berupa media gambar. Media ini dari segi ukuran relatif kecil sehingga tidak efektif digunakan untuk pembelajaran secara kelompok dan media ini tidak bisa menyampaikan objek secara nyata karena tidak ada unsur gerak dan suara. Hal ini membuat anak menajdi kurang aktif atau pasif, kegiatan bersifat monoton, pembelajaran kurang menarik dan inovatif sehingga anak mudah bosan dan sulit untuk fokus dalam kegiatan pembelajaran, hal ini menyebabkan anak lebih senang untuk mengganggu temannya. Dalam proses pembelajaran guru berperan sebagai pusat informasi dan anak sebagai penerima informasi.

Penerapan media pembelajaran audio visual memungkinkan anak akan menjadi lebih aktif dalam mengikuti pembelajaran, dapat menyampaikan apa yang sudah dipelajari atau disampaikan guru, serta mampu mengikuti aturan-aturan yang berlaku selama proses pembelajaran. Hal ini sesui dengan teori dari Brooks (dalam Dheini dkk, 2011:3.19) menyatakan kemampuan menyimak adalah sebagai salah satu kemampuan berbahasa awal yang harus dikembangkan, memerlukan kemampaun bahasa reseftif dan pengalaman, dimana anak sebagi penyimak secara aktif memproses dan memahami apa yang didengar. Dengan demikian kemampuan menyimak kelompok anak yang dibelajarkan menggunakan media pembelajaran audio visual lebih baik dibandingkan dengan kelompok anak yang dibelajarkan menggunakan media pembelajaran berupa media gambar.

Hasil penelitian ini diperkuat oleh penelitian Ermayanti dkk. (2017). Yang menunjukkan nilai rata-rata kemampuan menyimak kelompok eksperimen sebesar 37,82 sedangkan nilai ratarata kemampuan menyimak kelompok kontrol sebesar 16,20. Berdasarkan hasil perhitungan tersebut dapat disimpulkan bahwa nilai rata-rata kelompok eksperimen lebih besar dibandingkan dengan kelompok kontrol, serta terdapat perbedaan kemampuan menyimak dari kedua kelompok tersebut. Dilihat dari hasil uji-t diperoleh nilai t hitung adalah 10,267 sedangkan $\mathrm{t}$ tabel dengan taraf signifikan $5 \%$ dan $d k=(n 1+n 2)-2=30$ adalah 2,042. Dengan demikian $t$ hitung $>t$ tabel= $10,267>2,042$ maka hal ini berarti, $\mathrm{H} 0$ ditolak dan $\mathrm{H} 1$ diterima. sehingga dapat disimpulkan metode bercerita bermediakan audio visual berpengaruh terhadap anak kelompok B di Taman Kanakkanak Gugus III kecamatan Buleleng tahun ajaran 2016/2017. 
Hasil temuan Avianti dan Simatupang (2017) menunjukkan bahwa nilai rata-rata kemampuan menyimak anak untuk kegiatan sebelum perlakuan (pretest) adalah 4,4 dan rata-rata setelah perlakuan (posttest) adalah 7,3. Data tersebut kemudian dianalisis dengan uji jenjang bertanda Wilcoxon sehingga dapat diketahui bahwa $\mathrm{t}$ hitung $=0$ lebih kecil dari t tabel dengan taraf signifikan $5 \%$ dengan $\mathrm{N}=13$ diperoleh $\mathrm{t}$ tabel sebesar 17 ( $\mathrm{T}$ hitung $<\mathrm{t}$ tabel $=0<17$ ). Berdasarkan hasil tersebut dapat disimpulkan bahwa penggunaan media audio visual berpengaruh terhadap kemampuan menyimak anak kelompok B di TK Dharma Wanita Ngarjo Mojoanyar Mojokerto.

Berdasarkan pemaparan diatas, maka dapat disimpulkan bahwa terdapat perbedaan yang signifikan antara media pembelajaran audio visual dengan media gambar terhadap kemampuan menyimak anak kelompok B Taman Kanak-Kanak Gugus II kecamatan Buleleng Tahun Ajaran $2018 / 2019$.

\section{PENUTUP}

Berdasarkan pemaparan hasil penelitian dan pembahasan maka dapat disimpulkan bahwa terdapat perbedaan yang signifikan kemampuan menyimak antara kelompok anak yang diberikan media pembelajaran audio visual dan kelompok anak yang dibelajarkan menggunakan media gambar pada anak kelompok B TK Gugus II kecamatan Buleleng Tahun Ajaran 2018.2019. Hal ini terlihat dari hasil analisis data menggunakan SPPS 16.0 for windows diperoleh nilai sig (2-tailed) sebesar $=0,000$ sedangkan pada taraf signifikan $5 \%=0,05$ maka sig (2-tailed) $=0,000<0,05$ sehingga $\mathrm{H}_{0}$ ditolak menyatakan hasil posttest kelompok eksperimen dan kelompok adalah signifikan (ada perbedaan). Dengan demikian media pembelajaran audio visual berpengaruh terhadap kemampuan menyimak anak kelompok B TK Gugus II Kecamatan Buleleng Tahun Ajaran 2018/2019.

Berdasarkan haasil penelitian dan pembahasan, maka dapat diajukan beberapa saran sebagai bahan perimbangan Taman Kanak-kanak untuk kedepannya yaitu sebagi berikut. 1) Kepada guru disarankan agar mampu mengetahui karakteristik anak, sehingga guru mampu menstimulasi kemampuan anak sesuai dengan karakteristik anak. 2) Kepada kepala TK disarankan agar lebih banyak memberikan guru-guru pelatihan ataupun pembinaan mengenai strategi pengajaran yang sesuai dengan anak. 3) Kepada peneliti lain disarankan agar Penelitian tentang upaya meningkatkan kemampuan menyimak anak melalui media pembelajaran audio visual masih banyak kekurangan dan jauh dari sempurna. Oleh karena itu, peneliti lain hendaknya termotivasi lebih untuk melanjutkan dan melengkapi penelitian dengan menggunakan media pembelajaran serta metode pembelajaran yang lebih bervariasi untuk meningkatkan kemampuan menyimak anak.

\section{DAFTAR PUSTAKA}

Agung. A. A. Gede. 2014. Metodologi Penelitian Pendidikan. Malang: Aditya Media Publishing.

Antara, P. A. 2017. "FONEM ANAK: PEMEROLEHAN BAHASA PERTAMAN (Studi Kasus Tentang Pemerolehan Fonem Anak Pada Periode Praoperasional)" Vol 1. No 1.

Avianti, W dan N. D. Simatupang. 2017 "Pengaruh Media Audio Visual Terhadap Kemampuan Menyimak Kelompok B di TK Dharma Wanita Ngarjo Mojoanyar Mojokerto" Jurnal PAUD Teratai. Vol 06. No 03.

Dinda, C. 2017."Pengembangan Bahasa Anak Usia Dini Melalui Media Audio Visual Taman Kanak-kanak Assalam 1 Sukarame Bandar Lampung".

Dhieni, ddk. 2011.Metode Pengembangan Bahasa.Jakarta: UNIVERSITAS TERBUKA.

Doludea, A., dan L. Nuraeni. 2018. "Meningkatkan Keterampilan Menyimak Pada Anak Usia Dini 5-6 Tahun Dengan Metode Bercerita Melalui Wayang Kertas Di Tk Makedonia". CERIA (Cerdas Energik Responsif Inovatif Adaptif). Vol. 1. No. 1.

Ermayanti, L. W. K. Pudjawan dan L. P. P Mahadewi. 2017." Pengaruh Metode Bercerita Bermediakan Audio Visual Pembelajaran Terhadap Kemampuan Menyimak Anak Gugus III Kecamatan Buleleng" e_Journal Pendidikan Anak Usia Dini Universitas Pendidikan Ganesha.Vol 5.No 1. 
Filtria, H dan A.L.K. Sembiring. 2018. "Perkembangan Kognitif Anak Usia 5-6 tahun di Tinjau dari Tingkat Pendidikan Ibu di Paud Kasih Ibu Kecamatan Rumbai. PAUD Lectura: Jurnal Pendidikan Anak Usia Dini. Vol 1. No 2.

Hartati,S dan G. V. Novrika. 2018. "Using Education Vedio to Promoting Lostening Skill Children of 5-6 Years Old" Errly Childhood Educatioan Journal of Indonesia. Vol 1. N0. 1.

Karlina, D. N. A. A., dan T.D. Soesilo. 2018. "Meningkatkan Kemampuan Berbicara Anak TK B Usia 5-6 Tahun Melalui Digital Storytelling di TK Apple Kids Salatiga Semester I Tahun Ajaran 2017/2018". JPUD-Jurnal Pendidikan Usia Dini. Vol. 12. No 1.

Kartikadewi, C. A. S. Wahyuningsih dan W. Palupi. 2018. "Listening Skills In Children Aged 5-6 Years" National Seminar on Elementary Education. Vol 1. No 1.

Listyaninggrum, I. 2017. "Upaya Meningkatkan Kemampuan Menyimak Melalui Metode Bercerita dengan Media Ritatoon pada Anak Kelompok B di TK Pertiwi Japanan I Cawas Klaten.

Peraturan Menteri Pendidikan dan Kebudayann Republik Indonesia No. 137 Tahun 2014 tentang Kurikulum 2013 Pendidikan Anak Usia Dini

Santrock, J. W. 2002. Perkembangan Anak. Jakarta : Erlangga.

Sugiyono. 2017. Metode Penelitian Pendidikan Bandung:Alfabeta.

Tegeh, I M. 2009. Media Pembelajaran.Singaraja: Tidak diterbitkan.

Wati, E. R. 2016. Ragam Media Pembelajaran. Kata Pena.

Yuliana. 2018."Pengaruh Media Audio Visual Terhadap Keterampilan Menyimak Mata Pelajaran Bahasa Indonesia Kelas V Di SDN 1 Jaya Bandara lambung". 